AL-Ulum

Volume 15 Number 1 June 2015

Page 43 - 56

\title{
ZAKAT AND TAX; FROM THE SYNERGY TO OPTIMIZATION
}

\author{
Mustofa and Ahmad Khoirul Fata \\ IAIN Sultan Amai Gorontalo \\ (mustofatok@gmail.com, cakfata@gmail.com)
}

\begin{abstract}
Dualism dilemma between zakat and tax in Indonesia can be relatively mitigated by ratification of Act No. No. 38/1999 on Management of Zakat. In the regulation, zakat has been synergized with tax by placing zakat as a deduction from taxable income element (PKP). But so far it has not been given the significant impact on the acceptance of zakat and awareness of Muslims to pay zakat. There are also some problems in practical level that contribute to that fact. This article explores the zakat and tax synergy that have been achieved through Act No. 38 of 1999, the problems found in its execution, and of course an offer for a solution to optimize the role of zakat and tax for the people welfare. By examining same practice in some countries, this paper recommends zakat as a direct tax deduction (tax credit) as a strategic step in the effort to optimize the role of zakat.

Dilema dualisme zakat dan pajak di Indonesia relatif bisa diredakan melalui pengesahan Undang-undang No No 38/1999 tentang Pengelolaan Zakat. Dalam peraturan itu zakat telah disinergikan dengan pajak dengan menempatkan zakat sebagai unsur pengurang Penghasilan Kena Pajak (PKP). Namun sejauh ini ketentuan itu belum memberi pengaruh yang signifikan bagi penerimaan zakat maupun kesadaran umat Islam untuk membayar zakat. Selain itu juga terdapat problem di tingkat praktis yang turut berperan bagi kenyataan itu. Tulisan ini mencoba membahas sinergi yang telah tercapai melalui UU No 38 tahun 1999, problem-problem yang ditemukan dalam pelaksanaannya, dan tentu saja tawaran bagi solusi optimalisasi peran zakat dan pajak bagi kesejahteraan rakyat. Dengan mengkaji praktik di beberapa negara, tulisan ini merekomendasikan zakat sebagai pengurang pajak secara langsung (tax credit) sebagai langkah strategis dalam upaya optimalisasi peran zakat.
\end{abstract}

Keywords: Zakat, tax, Synergy, Optimize, UU No 38/1999. 


\section{A. Introduction}

Could be a good Muslim as well as a good citizen? The question is often heard formally considering Indonesia is not a state based on Islam. The relationship between Islam and the state in the context of Indonesia have ups and downs throughout its history. At one point, the Muslims and the country involved differences and tensions, but at other times both live a life in peaceful and harmoniously.

Ups and downs can be seen from a variety of symptoms that have colored the history of Indonesia. DI / TII case, depoliticization of Islam at the beginning of the New Order, the issue of banning the veil in schools, the case of the Social Fund Contribution Prize (SDSB), and the Tanjung Priok incident bleed into most symptoms of Islam-state tensions. But history also notes the relationship of harmony between Islam and the state as seen from the ratification of Islamic Law Compilation (KHI), permit Muslim to wear veil for girls in school, permits the establishment of Islamic banks, and the ratification of the Law No. 38 of 1999 on Zakat.

The law No. 38/1999 on Management of Zakat, it appears that between Islam and the state actually does not have to undergo a tense and confrontational relationship. Positive and harmonious relationships can be nurtured properly so that Muslims do not have to face the dilemma between how to be a good Muslim or being a good citizen. The law No. 38/1999 became a confirmation for the thesis that Muslims could practice their religion to the fullest and at the same time also become good citizens and obeys the rules.

However, the implementation of the synergies between zakat and the tax has not lasted optimal. Various problems also accompany the synergies that make public welfare as the main purpose of zakat and tax has not reached yet. Because it takes certain steps in order to optimize both.

In this article the authors attempt to discuss the finer points in the legal regulations related to the synergy between zakat and taxes in Indonesia. In addition, this paper also trying to unravel the problems, both formally and in practice legal implementation. At the end of the text, the solution will be given in order to achieve optimization zakat and tax synergies so that public welfare can be achieved.

The discussion in this article has important value because; First, zakat and tax are two methods of strategic financial mobilization to improve the welfare of the Indonesian people who are predominantly Muslim. Second, zakat and tax, although originating from different paradigms, but both have similarity, namely as a "duty" to be fulfilled. If the tax is the duty as a citizen, then the 
charity are required for religious reasons. However, both zakat and tax have same aim, namely to improve the welfare of society. ${ }^{1}$

\section{B. Between Zakat and Tax}

Zakat is derived from the Arabic Zakaa, which means thrive, grow, increase, cleanse the liver, fair, generous, virtue, healthy, and suitability. ${ }^{2}$ Or also significantly grow into large (namaa), increased (ziyadah), chastity (Taharah) and blessing (baraka). ${ }^{3}$

Wahbah al-Zuhayli defines zakat as the rights that obligated for the treasure. While al-Sayyid Sabiq interpreted it as part of Allah's right that paid by human for the poor people. Issued treasure is called "zakat (charity)" because it contains hope for blessings, self-cleaning, and the growth of goodness. ${ }^{4}$ Similarly Yusuf al-Qaradawi mentions that Zakat is an obligation that must be fulfilled to purify the soul of nature stingy and greedy, to purify treasure, and serves to redistribute wealth to those who are entitled / deficiency. ${ }^{5}$

Zakat becomes an important element in Islam. He is a pillar of the five pillars of Islam that the obligation has been stated clearly by Allah, Prophet Muhammad and ijma 'of Muslims. The important position of zakat can be seen from the fact that in the Qur'an it says is often referred to in conjunction with a word of prayer as much as 82 verses. In addition, a person who denies this obligation he can be classified as apostates and infidels, and could be given the death penalty, unless he reneged because of ignorance. ${ }^{6}$

However, a person can only be given zakat obligation if he meets several requirements, namely: independence, a Muslim, the treasure belongs to himself, has reached nisab, and has reached one haul. ${ }^{7}$ Results zakat then collected to be given to some groups in accordance with the provisions of Surat al - Tawbah verse 60, namely: indigent, poor, zakat manager, muallaf who has persuaded his heart, freeing slaves, people in debt, people who are struggling in the way of Allah and traveler (musafir).

${ }^{1}$ Mustafa Edwin Nasution, dkk. (ed), Indonesia Zakat and Development Report 2009, The repot in 2009,p. 97.

${ }^{2}$ Hans Wehr, A Dictionary of Modern Written Arabic (New York: Spoken Languange Service, 1976), p. 379.

${ }^{3}$ Wahbah al-Zuhayli, Fiqh Islam wa 'Adillatuh, Juz II (Damaskus: Dar al-Fikr, 1985), p.. 729; al-Sayyid Sabiq, Fiqh al-Sunnah, Juz I (Kairo: al-Fath li al-A'lam al-Islami, tt), p. 235

${ }^{4}$ Al-Zuhayli, ibid, p. 730; Sabiq, ibid, p. 235

5 Yusuf al-Qaradhawi, Fiqh al-Zakat: Dirasah Muqaranah li 'Ahkamiha wa Falsafatiha fi Dau'i al-Qur'an wa as-Sunnah, Juz I (Kairo: Maktabah Wahbah,1994 ), p. 5657.

${ }^{6}$ Lihat al-Zuhayli, Fiqh Islam, p. 733-734; Sabiq, Fiqh al-Sunnah, p. 235-238.

${ }^{7}$ Al-Zuhayli, ibid.; Sabiq, ibid, p. 240 
There are two types of zakat: zakat soul (fitrah) and zakat maal (wealth). Wealth that must be issued as zakat, they are: gold and silver, agricultural products such as grains and fruits, the results of trade, livestock, mining, and artifacts. ${ }^{8}$ Besides, contemporary Muslim scholars also made ijtihad (decision) zakat for wealth obtained from certain professions. ${ }^{9}$

In the period of Prophet Muhammad and Abu Bakr al-Siddiq, the main source of state finance consists of zakat, ghanimah, fa'i, and jizya. But after taking over Iraq Khalifah (Caliph) Umar bin Khattab proclaimed an attractive policy for levy on land (kharaj) to the population even though they had converted to Islam. Later on, practice of tax continues to be applied in the Islamic world with a variety of reasons, such as: 1) to achieve social security, 2) to fulfill the much needs of the country, while zakat is limited to eight asnaf, 3) to anticipate the greater danger which threatens the country or to the various needs of the country, 4) to fulfill the obligation of Jihad with their wealth, 6) tax paid used to fulfill the facilities and services of state. ${ }^{10}$

Terminology of tax in Islam known as dharibah which include tax (kharaj) and customs tax (ushur). Kharaj is an obligation imposed on land occupied by the Muslims through conquest or by the peace agreement, ${ }^{11}$ while ushur is a tax levied on property trade, associated with crossing the boundaries of Islamic countries both incoming and outgoing (export-import tax). ${ }^{12}$

Yusuf al-Qaradawi explained that taxes are compulsory contributions must be submitted by the taxpayer to the state, regardless of merit rewards of services that have been implemented by a public authority. The result, on the one hand, is used to cover public expenditures, and, on the other hand, is used to achieve some objectives of economic, social, political and other goals to be achieved by the state. ${ }^{13}$ While Athif Mahmud al-Banna explained that tax are compulsory contributions required by the state by force, and is final (irrevocable), because it is the role of the taxpayer in the burden and costs of public interest, without getting rewards benefits special nature. ${ }^{14}$

In the context of modern states, the tax becomes a very important sector for the source of state revenue exceeds the zakat. Even in later zakat is no

${ }^{8}$ Ibid, p. 243.

${ }^{9}$ Diskusi tentang penetapan zakat profesi bisa dilihat di Asmuni Mth, "Zakat Profesi dan Upaya Menuju Kesejahteraan Sosial”, Jurnal La Riba Vol I No 1, Juli 2007, p. 43-56

10 Safarni Husain, "Zakat Penghasilan sebagai Pengurang Penghasilan Kena Pajak", Risalah Hukum Vol 6 No 1, June 2010, p. 9-10.

${ }^{11}$ M. Abdul Mannan, Teori dan Praktek Ekonomi Islam, Trans. M. Nastangin (Yogyakarta: Dana Bakti Wakaf, 2007), p. 164.

${ }_{12}$ Abd. Azis Ali al-Naim, Nizam ad-Daraib fi al-Islam (Riyadh: tp., 1997), p. 280.

${ }^{13}$ Al-Qaradhawi, Fiqh al- Zakat, p. 70.

14 Al-Nabhan, al-Ittijah al-Jama'i fi at-Tashri' al-Iqtisadiy al-Islamiy (Beirut: Mu'assasah al-Risalah, 2005), p. 410. 
longer a source of state revenue. Zakat is located outside of the affairs of the state and is managed independently by the Muslim community. This condition makes the dilemma of Muslims; on the one hand they have to spend some money to pay taxes to the state and on the other side must also pay zakat as a form of religious observance. Of course the "double burden" financially burden the majority of Muslims are lower middle class.

As a "levies", zakat and taxation have some similarities that can be broken down as follows; First, zakat and taxation are equally coercive, involving managers, and aims to realize the public welfare. The fain was marked with various threats for which no carry it out. In the case of zakat, those who would deny it threatened to be an apostate, while the threat of a tax that can be a warning, a reprimand, forced letter, until the foreclosure. ${ }^{15}$

Third, in terms of management, as described in at-Taubah verse 60, zakat is managed by amil zakat who has a duty to levy and distribute Zakat to mustahiq (receiver). ${ }^{16}$ The management of tax obviously must be regulated by the state. This is in line with the definition of the tax itself, namely the contribution to the state (which can be imposed) that are owed by the mandatory pay according to the regulations, with no gain achievement back, which can be directly appointed, and the use is to finance general expenditures, in connection with the duty of the state to govern. ${ }^{17}$ Fourth, the dimensions of the destination, zakat and taxes have a social purpose to suppress the socio-economic gap in society and perform equalization property ownership for the common welfare. ${ }^{18}$

Although the meeting point can be traced from four dimensions of zakat and tax, both also contained several different aspects, namely on the naming, legal basis and nature of the obligations. In terms of naming, zakat means clean, holy, blessing, grow, beneficiaries, and growing. This means that every property will be issued zakat clean, growing, blessings, and growing. While the tax is derived from the word dharibah which etymologically means burden and sometimes also interpreted as jizya which means land tax (tribute) submitted by experts of Dhimmah (people who remained in disbelief, but subject to the rules of the Islamic government). ${ }^{19}$ Meanwhile, in terms of the legal basis and the nature of the obligation, zakat is determined based on the nas of the Qur'an and the Hadith of the Prophet who is qat'i, so the obligation is absolute and all time.

${ }^{15}$ Ibid, p.. 413.

${ }^{16}$ Ridwan Mas'ud dan Muhammad, Zakat \& Kemiskinan: Instrumen Pemberdayaan Ekonomi Umat (Yogyakarta: UII Press, 2005), p. 68.

${ }_{17}$ Al-Nabhan, al-Ittijah, p. 410.

18 Al-Qaradhawi, Fiqh al-Zakat, p.. 82; Sjechul Hadi Permono, Pendayagunaan Zakat disamping Pajak dalam Rangka Pembangunan Nasional, Disertasi, IAIN Syarif Hidayatullah Jakarta, 1988, p. 119.

${ }^{19}$ Mannan, Teori dan Praktek, p. 164. 
According to Yusuf al-Qaradawi Zakat is an obligation that is permanent and continuous. It will continue as long as there is Islam and Muslims still exist on earth. As well as prayer (shalat), zakat is a pillar of religion and the basic teachings of Islam. Zakat is in order taqarrub worship to God, therefore requires sincerity when fulfilled, besides to worship that contains various lessons that are essential in order to improve the welfare of the people. Therefore, in the discussion of fiqh, studies zakat inserted into the worship, along with studies on Taharah (ablution), prayer, fasting, and pilgrimage (hajj). ${ }^{20}$

Unlike zakat, the tax is determined based on a secular instrument or by the government / state governed by laws / regulations. In Indonesia, the tax laws is sourced and based on Chapter VIII It Finance Section 23A Act of 1945 which states that "taxes and other levies for the purposes coercive state governed by law".

The basic rule was later clarified in more detail in several laws. Here are the taxation laws in force since the 1983 taxation reformation until now: ${ }^{21}$

1. Law No. 6 of 1983 concerning General Provisions and Tax Procedures, has undergone several changes to Law No. 9 of 1994, Law No. 16 of 2000 and the last Act No. 28 of 2007 which is effective from the 2008 tax year.

2. Law No. 7 of 1983 on Income Tax, has undergone several changes to Law No. 7 of 1991, Law No. 10 of 1994, Law No. 17 of 2000 and the last Act No. 36 of 2008 which is effective from the tax year 2009,

3. Law No. 8 of 1983 on Value Added Tax on Goods and Services and Sales Tax on Luxury goods, has undergone several changes to Law No. 11 of 1994, and Law No. 42 Year 2009.

4. Law No. 12 of 1985 on Land and Building Tax, has undergone a change last by Act No. 12 of 1994 .

5. Law No. 13 of 1985 on Customs Materei.

6. Law No. 21 of 1997 on the Tax on Acquisition of Land and Building, has undergone a change with Law No. 20 of 2000.

7. Law No. 10 of 1995 on Customs, amended by Act No. 17 of 2006.

8. Law No. 11 of 1995 on excise has been amended by Law No. 39 of 2007.

9. Act No. 17 of 1997 on the Tax Dispute Settlement Body that was later replaced by Law No. 14 of 2002 on the Tax Court.

10. Law No. 24 of 2000 on International Agreements (tax treaty).

11. Law No. 18 of 1997 on Regional Taxes and Levies, has undergone a change with Law No. 34 of 2000.

${ }^{20}$ Al-Qaradhawi, Fiqh al-Zakat, p. 85.

${ }^{21}$ Dikutip dari Ahmadi H Lazuardi, "Mengenal Undang-undang Pajak di Indonesia dan Perubahannya," contained in http://pajakita.blogspot.com/2009/04/mengenal-undang-undangperpajakan.html (accessed on 24-1-2015). 


\section{Zakat and Tax Management}

It was clear enough on Surah At-Tawbah verse 60 explains that the management of zakat is not merely done individually, from muzakki submitted directly to mustahik, but carried out by a specialized agency dealing with charity and is called Zakat, which is in charge of outreach to the community, do billing, collection and distribution accurately and correctly.

In addition, as the command of the Qur'an, by Amil Zakat, zakat management has some advantages or benefactions, among others, the following: ${ }^{22}$ First, to ensure predictability and discipline of tax payers; second, keeping feelings of inferiority from mustahik zakat when dealing directly receive zakat from compulsory zakat (muzakki); Third, to achieve efficiency, effectiveness, and targeted the use of Zakat according to the priorities that exist in a place; fourth, to show the greatness of Islam in the spirit of the organization of the Islamic state and government.

While in Law No. 38 of 1999 Chapter II Article 5 stated that the management of zakat through amil zakat aims:

1. Improve services to the public in accordance with the guidance practice regular zakat religion.

2. Improve the function and role of religious institutions in an effort to realize the public welfare and social justice.

3. Improving the effectiveness and efficiency of zakat.

The law also stated the government does not function as an operator that manages zakat but as a regulator, a motivator, coordinator and facilitator. With the duties and functions the government encourage and facilitate so that management conducted by amil zakat (Badan Amil Zakat [BAZ] and the Institute of Zakat [LAZ]) can be conducted in a professional, trustworthy and transparent so that the zakat management objectives for the greatest benefit and prosperity of the people can be achieved. ${ }^{23}$

In contrast to the tax administration is firmly regulated by the state, according to the definition of the tax itself, namely the contribution to the state (which can be imposed) that are owed by the mandatory pay according to the regulations, with no gain achievement back, which can be directly appointed,

22 Abdurrahman Qadir, Zakat Dalam Dimensi Mahdhah dan Sosial (Jakarta: Raja Grafindo Persada, 1998), p.43.

${ }^{23}$ Umrotul Khasanah, Manajemen Zakat Modern : Instrumen Pemberdayaan Ekonomi Umat (Malang : UIN-Maliki Press, 2010), p. 12. 
and the point is to finance general expenditures, related to the duty of the state to govern. ${ }^{24}$

\section{The Implementation Problem in Zakat and Taxes}

Enactment of the Law No. 38/1999 on Management of Zakat bring fresh wind to the development of zakat management organizations, particularly under the guidance of the Ministry of Religion and Local Government or independent agency established by the community. ${ }^{25}$

Along with the efforts to socialize the new paradigm that zakat, donation, and alms (ZIS), not just one of the pillars of Islam, but also as an Islamic financial system which has an important and strategic role in the lives of Muslims, mainly to cope with social problems, economic, and humanitarian. The rise of the discourse of zakat should further encourage the growth of a synergistic movement of Muslims to solve social problems in the country, such as poverty, unemployment and the quality of human resources is low due to the low level of education.

Potential Zakat of Indonesian people are very great to be exploited resolve the problems faced by the people. But unfortunately it's untapped potential optimally. In a survey conducted Baznas shows the potential zakat Indonesia reached Rp 270 trillion, but only absorbed about 1 percent. ${ }^{26}$

There are four reasons zakat has not run optimally in Indonesia, after Zakat Management Act socialized. First, awareness of people who are relatively less or uneven in carrying out religious obligations associated with the assets and the income it receives. Second, confidence in zakat management organization has not grown evenly. This is connected with the professionalism of institutions and benefits where the institution itself is not perceived or not easily accessible by every citizen who needs it. Third, the example of the formal authorities, such as the legislature, executive and judiciary are still not maximized. Fourth, low of power and speed of analysis and evaluation of the policies that had been issued. It is not infrequently an existing policy in fact was not able to accommodate and anticipate the dynamics of rapid development in the field. ${ }^{27}$

${ }^{24}$ Subiyakto Indra Kesuma, Mengenal Dasar-dasar Perpajakan (Surabaya: Usaha Nasional Indonesia, 1987), p.. 13.

${ }^{25}$ Eri Sudewo, Manajemen Zakat: Tinggalkan 15 Tradisi, Terapkan 4 Prinsip Dasar (Ciputat: Insitut Manajemen Zakat, 2004), p. 90.

26 "Potensi Zakat Maksimal" dalam http://www.republika.co.id/berita/koran/news-update/14/01/23/mzuzfv-potensi-zakat-belummaksimal (accessed on 22-1-2015)

${ }^{27}$ Nasution, et. al. (ed.), Indonesia Zakat, p. 62. 
Absolutely, the four problems are challenges that must be answered by the government, mainly by Badan Amil Zakat / BAZ and Amil Zakat Institution / LAZ scattered throughout the country. However, apart from the issue of professionalism zakat institutions in Indonesia, it is better if we look at the dimensions of zakat and tax practice.

The dualism of zakat and tax was perceived by Muslims since the post- independence until the end 90 s led to the double burden which in turn led Muslims are reluctant to implement one of two of their obligations ; choose between paying taxes or zakat. Although the opinion jumhur ( majority ) Muslim scholars, including Imam Shafi'i, stating that both shall be issued, meaning that paying tax does not terminate the obligation to pay zakat, should be recognized in practice it is burdensome Muslims in Indonesia. ${ }^{28}$

Some government policies initiated to minimize the excesses of the double burden, one of them through Zakat Management Act and the Income Tax Act (Income Tax). This Act stipulates that the zakat paid by individual taxpayers and corporate taxpayers (business manager and owner of a business entity) to the agency or institution recognized by the government zakat becomes an element of taxable income deduction (PKP) or deduction from gross income. $^{29}$

In the Indonesian Government Regulation No. 60 Year 2010 on Zakat or donations compulsory religious can deductible from gross income, mentioned include: (a) zakat on income paid by an individual Taxpayer Moslems and / or by a corporate taxpayer domestically owned by adherents of Islam to the body amil amil zakat zakat or institution established or approved by the Government; or (b) compulsory religious contribution for an individual taxpayer faiths other than Islam and / or by a corporate taxpayer in the country owned by a religion other than Islam, which is recognized in Indonesia are paid for religious institutions established or approved by the Government.

However, the incentive element of zakat as a deduction from taxable income (PKP) so far has not given a significant influence, both in terms of acceptance of zakat and in terms of awareness of Muslims as individuals and business entities to pay. Therefore, practitioners and managers proposed zakat "zakat as a tax deduction (tax credit)," such as the system in Malaysia. But until now, such proposals have not been accommodated in the legislation. ${ }^{30}$

Apart from professional management of zakat and zakat formal rules and taxes, other issues that no less importance is a matter of public confidence in the

\footnotetext{
${ }^{28}$ Qadir, Zakat dalam, p. 59.

${ }^{29}$ Nasution, dkk. (ed.), Indonesia Zakat, p. 97.

${ }^{30}$ Sudewo, Manajemen, p.. 76.
} 
institution of zakat, particularly designated by the state and taxes, and coordination among zakat managers which has not maximally established. ${ }^{31}$

\section{E. Optimization of Zakat and Taxes}

Although zakat and taxation have some different points, but both the same end goal, namely the welfare of the people and the nation in many areas of life, such as economics, education, health and so forth. Implementing zakat and tax well is evidence of submission and obedience to the teachings of religion and state rules, which do not necessarily to be opposed to one another. Moreover, from the aspects of management, both must be managed in a trustworthy, transparent, accountable and professional. Either zakat or taxation should be managed by an institution that has the authority and who have a duty of state / government / society. In the management of zakat for example, explicitly in the Qur'an and Hadith were raised about the necessity zakat managed by amil zakat. ${ }^{32}$

But, how to synergize tax and zakat in order to realize their goals? At least there are two views in answering those two questions. First, the group argued that the policy of zakat as a deduction from the gross income of the taxpayer (tax deductible), as adopted over the years, is the most appropriate choice. Secondly, the group believes that zakat as a tax deduction policies directly (tax credit) is a strategic step in the effort to explore the potential of zakat, as well as integrating it more deeply in the national economy. ${ }^{33}$

There are at least two basic arguments that reinforce this second group statement. First, from the country financial perspective, when there are synergies and integration process zakat on fiscal policy, there will be a number of benefits to be gained, namely the expansion of the base muzakki and taxpayers, as well as help ease the burden on the state budget in terms of poverty reduction budget. ${ }^{3}$

Through good coordination between authorities charity with tax authorities, the identification compulsory zakat (muzakki) and the taxpayer will be more extensive, so the expected income tax and zakat will increase. It is empirically proven by Malaysia, where the zakat and tax revenues actually increased after the implementation of policies zakat as a tax credit. There is no

${ }^{31}$ Sjechul Hadi Permono, Pendayagunaan Zakat, p.. 123; lihat juga "Lembaga Amil Zakat Lebih Sensitif dari Bank", in http://www.merdeka.com/khas/lembaga-amil-zakat-lebihsensitif-dari-bank-wawancara-agustianto-2.html (accessed on 21-1-2015)

${ }^{32}$ See QS. at-Taubah (9): 60 and 103. 2010, p. 12.

33 "Perlu Optimalisasi Pengumpulan Zakat", Harian Republika, Friday, 13 ${ }^{\text {th }}$ August

${ }^{34}$ Soeparman Soemahamijaya, Pajak Berasarkan Azas Gotong Royong (Bandung: UNPAD Press, 2000), p. 37. 
trade off between tax revenue to zakat. ${ }^{35}$ Besides Malaysia, other countries are also implementing a similar policy, namely social donation as a tax deduction directly.

In Peurto Rico, for example, the number of social donations which may be filed as the tax credit is the range of three percent (lower limit) to 15 percent (the upper limit). ${ }^{36}$ If someone donates its earnings within that range, then the tax incentives granted is equal to one-third (33.33\%) of total donations. For example a person has an income of $\mathrm{Rp} 100$ million / year, and he donated Rp 15 million (the upper limit of the claims, 15\%) for social purposes, then the numbers that can be claimed as a tax rebate is one third of Rp 15 million, Rp 5 million. So if he has a tax liability, such as Rp 22 million, then he stayed to pay Rp 17 million.

Social acceptance in Peurto Rico donations increased significantly if the lower limit of the amount of donations that can be claimed as a tax credit, reduced to one percent or eliminated altogether, and the upper limit goes up to 50 percent of the total income of a person. From the simulations that were carried out, the policy proved successful to boost acceptance of social donations, far exceeding the potential loss of state tax revenue. In other words, the social value of this donation will be greater than the amount of taxes lost due to corruption and other leakages.

While the second benefits, the existence of zakat will minimize the burden of the state budget in the alleviation of poverty. For example, if it was allocated $\mathrm{Rp} 86$ trillion for poverty reduction, then every poor person would receive an average aid of $\mathrm{Rp} 2.77$ million per year, or $\mathrm{Rp} 230$ thousand / month. If the zakat can be realized only Rp 100 trillion, or equivalent to 46.08 percent of the total potential of zakat which reached Rp 217 trillion, ${ }^{37}$ then there will be

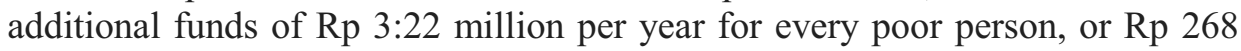
thousand per month. Therefore, the poverty alleviation program coordination between relevant ministries to BAZ and LAZ is necessary for poverty reduction programs can be accelerated by both.

Actually, Zakat has potential to become an effective tool of economic distribution. Zakat becomes a medium of distribution of wealth from the rich to the poor, so that economic growth with equity that has been touted can be

35 Saneb Ahmad, dkk., Penswastaan Institusi Zakat dan Kesannya terhadap Pembayaran Secara Formal di Malaysia, International Journal of Management Studies, 13 (2), 2006, p. 182.

${ }^{36}$ Damanhur, Mewujudkan Sistem Perpajakan Perspektif Islam (Studi Kasus Sikap Masyarakat terhadap Pajak Pendapatan dan Bazis di Nanggroe Aceh Darussalam), Prosiding, Persidangan Antarabangsa Pembangunan Aceh, 26-27 December 2006, UKM Bangi, p.. 10.

http://www.republika.co.id/berita/koran/news-update/14/01/23/mzuzfv-potensi-zakat-belummaksimal (accessed on 22-1-2015) 
realized well. ${ }^{38}$ Distribution of wealth, in turn, will provide a very large multiplier effects, one of which is to boost economic growth. This is reasonable because the charity will boost consumption and the investment among the poor. ${ }^{39}$

The effectiveness of Zakat in poverty reduction and economic improvement among poor evident that was recorded and analyzed by BAZNAS, explaining that the amount of mustahiq who received zakat aid reached 2.8 million. If it was percentage, this figure is equivalent to about 9:03 per cent of the total poor population in the country. Then in a variety of researches that has been conducted shows that the charity funds managed by BAZ and LAZ mustahiq able to reduce the amount of poverty, and the depth and severity of poverty mustahiq. ${ }^{40}$

\section{F. Conclusion}

Based on the description that has been stated above, it can be concluded that although between zakat and taxes have differences in several ways, but both have the same end goal, namely the welfare of people in various areas of life, such as economics, education, health and other etc.

If zakat and tax synergized and professionally managed, the benefits to be derived such as, the expansion of the base muzakki and taxpayers and help to ease the burden on the state budget in the poverty alleviation program. Therefore, good coordination between the authorities zakat with tax authorities, in order muzakki and the taxpayer can identify broadly, is absolutely necessary. And the result is the income tax and zakat will also increase. If the income tax and zakat will increase, the effort for the welfare of the people's life in Indonesia is increasing as well.

And more importantly than that, owing to the synergy people can fill religious obligations and state in the same time so in can eliminate the dilemma of Muslims, between being an obedient servant of God or being a good citizen.

38

"Pola dan Kecendrungan

Masyarakat Berzakat," in http://www.imz.or.id/new/publication/96/pola-dan-kecenderungan-masyarakatberzakat/?lang=id (accessed on 22-1-2015).

${ }^{39}$ Munrokhim Misanam, dkk., Ekonomi Islam (Jakarta: Rajagrafindo Persada, 2008), p. 501 .

${ }^{40}$ Nasution, et. al., Indonesia Zakat, p. 20 


\section{REFERENCE}

Ahmad, Saneb, dkk. 2006, "Penswastaan Institusi Zakat dan Kesannya terhadap Pembayaran Secara Formal di Malaysia", International Journal of Management Studies, Vol 13 No 2.

Al-Nabhan, 2005, al-Ittijah al-Jama'i fi at-Tashri' al-Iqtisadiy al-Islamiy. Beirut: Mu'assasah al-Risalah.

Al-Naim, Abd. Azis Ali. 1997, Nizam ad-Daraib fi al-Islam. Riyadh: tp.

Al-Qaradhwi, Yusuf. 1994, Fiqh al-Zakat: Dirasah Muqaranah li 'Ahkamiha wa Falsafatiha fi Dau'i al-Qur'an wa as-Sunnah, Juz I. Kairo: Maktabah Wahbah.

Al-Zuhayli, Wahbah. 1985, Fiqh Islam wa 'Adillatuh, Juz II. Damaskus: Dar al-Fikr.

Damanhur, "Mewujudkan Sistem Perpajakan Perspektif Islam (Studi Kasus Sikap Masyarakat terhadap Pajak Pendapatan dan Bazis di Nanggroe Aceh Darussalam)", Prosiding, Persidangan Antarabangsa Pembangunan Aceh, 26-27 Desember 2006, UKM Bangi.

Husain, Safarni. "Zakat Penghasilan sebagai Pengurang Penghasilan Kena Pajak”. Risalah Hukum, Vol 6 No 1, Juni 2010.

Kesuma, Subiyakto Indra. 1987. Mengenal Dasar-dasar Perpajakan. Surabaya: Usaha Nasional Indonesia.

Khasanah, Umrotul. 2010, Manajemen Zakat Modern : Instrumen Pemberdayaan Ekonomi Umat. Malang : UIN-Maliki Press.

Lazuardi, Ahmadi H. "Mengenal Undang-undang Pajak di Indonesia dan Perubahannya." Contained in http://pajakita.blogspot.com/2009/04/mengenal-undang-undangperpajakan.html (Accessed on 24-1-2015).

Mannan, M. Abdul. 2007. Teori dan Praktek Ekonomi Islam, Terj. M. Nastangin. Yogyakarta: Dana Bakti Wakaf.

Mas'ud, Ridwan dan Muhammad, 2005, Zakat \& Kemiskinan: Instrumen Pemberdayaan Ekonomi Umat. Yogyakarta: UII Press.

Misanam, Munrokhim (ed). 2008, Ekonomi Islam. Jakarta: Rajagrafindo Persada.

Mth, Asmuni. 2007, "Zakat Profesi dan Upaya Menuju Kesejahteraan Sosial”. Journal of La Riba, Vol I No 1, July. 
Nasution, Mustafa Edwin. Indonesia Zakat and Development Report 2009. Research Report as the result of coordination among PEBS FEUI, CID, and DD Republika.

Permono, Sjechul Hadi. 1988, Pendayagunaan Zakat disamping Pajak dalam Rangka Pembangunan Nasional, Disertasi, IAIN Syarif Hidayatullah Jakarta.

Qadir, Abdurrahman. 1998, Zakat Dalam Dimensi Mahdhah dan Sosial. Jakarta: Raja Grafindo Persada.

Sabiq, al-Sayyid. Tt. Fiqh al-Sunnah, Juz I. Kairo: al-Fath li al-A'lam al-Islami.

Soemahamijaya, Soeparman. 2000, Pajak Berasarkan Azas Gotong Royong. Bandung: UNPAD Press.

Sudewo, Eri. 2004, Manajemen Zakat: Tinggalkan 15 Tradisi, Terapkan 4 Prinsip Dasar. Ciputat: Insitut Manajemen Zakat.

Wehr, Hans. 1976, A Dictionary of Modern Written Arabic. New York: Spoken Languange Service.

"Lembaga Amil Zakat Lebih Sensitif dari Bank", in

http://www.merdeka.com/khas/lembaga-amil-zakat-lebih-sensitif-daribank-wawancara-agustianto-2.html (diakses 21-1-2015)

“Perlu Optimalisasi Pengumpulan Zakat”, Harian Republika, Friday, $13^{\text {th }}$ August 2010.

"Pola dan Kecendrungan Masyarakat Berzakat," in http://www.imz.or.id/new/publication/96/pola-dan-kecenderunganmasyarakat-berzakat/?lang=id (accessed on 22-1-2015).

"Potensi Zakat Belum Maksimal" dalam http://www.republika.co.id/berita/koran/newsupdate/14/01/23/mzuzfv-potensi-zakat-belum-maksimal (accessed on 22-1-2015) 